19th.-Is very well, and his aspect very good; still a little pain in the lumbar region, especially after micturition; pulse 96; tongue a little clammy; sweats usually a good deal towards morning; spleen continues much the same ; induration of the left lobe of the liver can be felt, but he does not complain of pain in that region; wound completely cicatrized.

April 1st. Walking about apparently in good health; complains of nothing but weakness.

7th.-Discharged, cured.

\section{THE NEW LABEL FOR ENGLISH SURGEONS.}

\author{
To the Editor of THE LANCET.
}

SrR, - I beg to forward to you my name, as that of one who is favourable to the object of an Aggregate Meeting and Conference, under the presidency of Mr. Guthrie. I, as a member, deeply deplore the false step of the National Association, in attempting to found a new hall with the débris of the extinguished company of Blackfriars. Do not we consider the College of Surgeons as our alma mater? Have we not virtually a share in that institution? Or are we, after paying a large fee for admission, to be contemptuously looked down uron, and thrust into a thing ycleped a "Royal College of General Practitioners"? Then, as SURGEors holding a status in society, forming the greater portion of the tripartite section by almost traditiona usages termed "the professions"- shall we, I say, quietly sit down, labelled, General Practitioners, mulcted if we dare to use the name, of " surgeon;" and all for what?- to serve as tools in the hands of designing men,--to favour the views of those who have everything to gain and nothing to lose. But $I$ trust that higher, more honourable and ennobling sentiments pervade the ranks of our profession.-I am, Sir, your most obedient servant,

Pellinge, near Ashford, June 8th, 1845. F. W. Pitrock.

\section{REDUCTION OF MEDICINE TO NOTHING.} To the Editor of THE LANCET.

Srr,-I have not yet wasted my time in looking into Dr. Epps's "rejected cases," but as I have been making a few calculations connected with the subject of homnopathy, I send them to you for iusertion, in order that they may be introduced into some work or other on the "Delicately Scientific Character of Homoopathy."

The usual dose of chalk and other strong medicines (according to the Homcopathic Pharmacopceia) is a decillionth of a grain The way in which this minute division is arrived at, is by mixing one grain of medicine with 999 of sugar of milk; then taking one grain of the mixture, and mixing it with 999 grains more of sugar of milk, and so on for thirty times. The last thousand is supposed to contain a decillionth of medicine in each grain of the mixture! Or if the homcopathists wished to make a liquid, they would take a two-ounce phial, drop one drop of medicine into it, then fill it, and fill and empty it thirty times with distilled water, reserving the last washing, which will contain much more than a decillionth in each drop, for obvious reasons. Now, a decillion takes 61 figures for its enumeration; when brought into tons it requires 53 figures-viz., 58,000 octillions, and as the earth, at a specific gravity of three, weighs about 3,248 trillions of tons, you will find that, if you wish to mix it in bulk, it would require above 1\%-quintillion times the weight of our earth to mix with one grain of medicine.

The following will give some idea of a quintillion:-A watch ticks five times in two seconds, or 150 times in a minute, which amounts to $78,840,000$ times in a year. Yet it will take above 13,000 trillions of years to tick a quintillion-times; and this is more than two trillion times as long as the human race has existed; for a watch will only tick $473,040,000,000$ in 6000 years.

I remain, Sir, your most obedient servant, Babbage's Calculating Machine.

June 2nd, 1845

\section{A BITTER DOSE FOR THE APOTHECARY- COMMITTEE.}

TuE following letter was addressed to the Commitiee of the National Association, on the 18th instant:-

Gentremen,-I forwarded my subscription to the National Association, under the influence of the following reasons:-

1st. Because, under the conviction that the new Charter of the College, and the then proposed Medical Bill, which opened the practice of medicine to any one however unqualified, emanated from the same source, I was desirous to express my sense of the injustice of both the Charter and the Bill.

2ndly. I considered that an Association which would direct its best efforts to the reforming of both Charter and College, keeping in view the welfare and honour of the College, which we have all sworn to maintain, would, in all probability, effect the desired object, without any severance from the latter.

I now withdraw my name from your list of members, because,

Ist. I think that the main object kept in view by your Committee has been the establishing a separate College rather than the reform of the old one.

2ndly. I think that the proposals made by your Committee to the College prove this, as being of a character which it was evident the College could not entertain, without losing somewhat of that high character which it has certainly attained.

3 rdly. I perceive that, according to your own showing, your members consist, in part, of unqualified persons, and I am very desirous that my name should be at once withdrawn from among those with whom I have no interest in common; and here I may remark, that the immense number of tradesmen professing to be surgeons, but keeping an open trading shop, which one sees in and about London, may justly make the College jealous of the respectability of its members, and I trust the day is not far distant, when not only this class of trading professionals, but also they who seek their remuneration for their professional services through their patients' stomachs, will be on all hands considered as degrading a profession which should stand ou far higher ground. I am, gentlemen, your most obedient servant,

Leamington, June $18 \mathrm{th}, 1845$. John Prichard.

\section{THE TERM "GENERAL PRACTITIONER."}

A communication has been addressed by Mr. J. Massey, of James-street, Nottingham, to the Secretaries of the Committee of the National Association, containing some criticisms on the "Transactions" dated June 2nd, sent to us for publication in The Lancet, but of which we are able to find room for only the following portions:-

"Nottingham, June $7 \mathrm{th}, 1845$.

"Gentlemen,-A few days since, I received the "Transactions' of the Association of General Practitioners. I object in toto to the name of Royal College of 'General Practitioners;' if any members of the College wish for any other distinguishing title, (than that of surgeon,) let them find one. I see no reason why we should allow them to usurp ours. By registering as general practitioners, we identify ourselves with that body exclusively, and, in my opinion, allow ourselves to be an inferior grade of medical practitioner's. It is merely another name for Apothecary. * * * *

"In my opinion, it would be better to remain as we are, than allow these unjust and most illiberal distinctions. The term General Practitioner is, I repeat, only another name for Apothecary, and will (by the public) be received as such. We give up our position, and register as general practitioners. We cannot, under the Bill, register (unless we be fellows) as surgeons, and practise as general practitioners. If we register as surgeons, we must practise as pure surgeons. Nor can I see why we should be parties to those succeeding us becoming general practitioners, and not be allowed to register as surgeons until they are twenty-six years. That is also very unjust.

"I should have been glad to see Mrr. Wakley's name in the list of the Committee. It would have given me much more satisfaction in your proceedings. It appears to me to have been a great omission, considering the immense benefit which has resulted from his exertions in the cause of medical reform; his exposure of the attendance, or, more properly speaking, the nonattendance of the surgeons at the hospitals; his exertions both in and out of Parliament; the framing of the Medical Witnesses Act; all convince me the more strongly that his opinions ought to have great weight; nor ought he to be overlooked and slighted in this last and final struggle to relieve the profession from the difficulties it has long contended against.

"The conduct of the College of Surgeons is looked apon by all with the greatest possible indignation. The election of parties to the fellowship because they were connected with hospitals, was unjust in the highest degree. Gentlemen were elected whose appointments were obtained, in very many instances, only because their parents had held them before, and from other interested motives, instead of throwing open the fellowship to all who were willing to submit to an examination to test their ability for it.

"Mr. Wakley's late motion in the House of Commons was a proper one, and ought to have been followed up energetically by the Association.

"The tendency of the Bill will be to degrade the general practitioner, and therefore I must, for the present, withdraw from it. I am, gentlemen, your obedient servant, 